UDC 004.738.5:347.441.142.2;004.738.5:339

CERIF: S150, S186

\author{
Dina Prokić, LLM*
}

\title{
THE ADOPTION OF THE UNITED NATIONS CONVENTION ON THE USE OF ELECTRONIC COMMUNICATIONS IN INTERNATIONAL CONTRACTS IN SERBIA - A WAY TO FACILITATE CROSS-BORDER TRADE
}

In the recent decades e-commerce has gained momentum. However, certain obstacles, such as cross-country legal differences, prevent e-commerce from flourishing. In an attempt to overcome these hurdles, the United Nations Commission on International Trade Law prepared a uniform framework, which the United Nations General Assembly adopted in 2005 as the Convention on the Use of Electronic Communications in International Contracts. The article addresses the Convention's main features and compares them to the Serbian laws in the area of e-commerce. Furthermore, the article highlights how the Convention could inspire reform of certain national regulatory solutions that currently complicate or prevent international trade. Finally, the article discusses the beneficial effects that the adoption of the Convention's principles in domestic legislation would have on economy and the ICT sector.

Key words: Convention on the Use of Electronic Communications in International Contracts. - Electronic commerce. - Electronic signature. Possible reform of the current state of the law.

* Former student of the University of Belgrade, Faculty of Law, dina.prokic@ gmail.com. The author expresses her sincere gratitude to Mr. Luca Castellani, the legal officer in the Secretariat of the United Nations Commission on International Trade Law (UNCITRAL), who encouraged the author to undertake this endeavor, by giving support, providing advice and valuable comments throughout the writing of this paper. 


\section{INTRODUCTION}

The Organization for Economic Co-operation and Development ("OECD") defines "e-commerce" as "transactions for the sale or purchase of goods and services conducted over computer networks by methods specifically designed for the purpose of receiving or placing of order". ${ }^{1}$ "E-commerce" may also be understood as commercial transactions, which are carried out by means of electronic data interchange and other means of communication. ${ }^{2}$ This article will attach the latter, slightly more "flexible" meaning to the term.

Despite the numerous positive effects of e-commerce - it reduces operational costs, enlarges market scope, and strengthens competition by lowering barriers to entry ${ }^{3}$ - various obstacles still prevent e-commerce from flourishing. One of those obstacles is cross-country legal differences. ${ }^{4}$ Many international organizations have actively searched for suitable solutions from the time when e-commerce began to gain momentum. The United Nations Commission on International Trade Law (the "UNCITRAL") is one of them.

As the core legal body of the United Nations system in the field of international trade law, UNCITRAL focuses on the modernization and harmonization of rules on international business by, inter alia, "preparing or promoting the adoption of new international conventions, model laws and uniform laws [...]." In the late 1980s UNCITRAL undertook the task of formulating uniform private law standards for electronic commerce. ${ }^{6}$ The first legislative text to be produced was the Model Law on Electronic Commerce, 1996 (complemented in 1998; the "MLEC"), followed by the Model Law on Electronic Signatures, 2001 (the "MLES"). Considering their wide acceptance, both model laws are deemed "global legislative standards in their fields, and the principles underpinning them constitute the pillars of global electronic commerce law" Nevertheless, these

1 OECD Directorate for science, technology and industry; Committee for information, computer and communications skills, "Electronic and Mobile Commerce" DSTI/ ICCP/IE/IIS(2012)1/FINAL, 26 July 2013, 6 (“OECD Document”).

2 Model Law on Electronic Commerce, Preamble.

3 OECD Document, 7.

4 Ibid., 26.

5 Article 8 (c), UN General Assembly Resolution 2205 (XXI) on the Establishment of the United Nations Commission on International Trade Law, http://www.uncitral. org/uncitral/en/about/origin.html, last visited 15 July 2014.

6 J.A. Estrella Faria, "The United Nations Convention on the Use of Electronic Communications in International Contracts - An Introductory Note," International and Comparative Law Quarterly 55/2006, 689.

7 L.G. Castellani, "The United Nations Convention on the Use of Electronic Communications in International Contracts at Ten: Practical Relevance and Lessons Learned," Journal of Law, Society and Development 3/2016, 132. 
texts have a "limit" inherent to their "soft law" nature. ${ }^{8}$ In particular, states, when enacting their provisions, may vary them and thus diminish uniformity. That is why in 2002 UNCITRAL began the work on the Convention on the Use of Electronic Communications in International Contracts, which was adopted by the UN General Assembly in 2005 (the "Convention" or the "e-CC"). 9

\section{THE SCOPE OF THE CONVENTION}

The e-CC applies to cross-border business-to-business ("B2B") transactions, thus excluding consumer contracts. The restricted scope of the Convention's application is unsurprising, considering that roughly $90 \%$ of the value of e-commerce transactions comes from B2B. ${ }^{10}$ Moreover, consumer protection rules are domestic in nature, meaning that they vary from jurisdiction to jurisdiction. ${ }^{11}$ Other UNCITRAL texts, such as the UN Convention on Contracts for the International Sale of Goods, 1980 (the "CISG") ${ }^{12}$, contain similar exclusions (e.g. Article 2(a)).

Similar to other UNCITRAL texts, the e-CC applies to contracts concluded between parties whose places of business are in different States. ${ }^{13}$ It is not necessary, however, for both States to be contracting States as long as the rules of private international law lead to the application of the e-CC. ${ }^{14}$

Considering that the Convention aims at providing solutions acceptable to "States with different legal, social and economic systems", 15

\footnotetext{
8 Ibid.

9 The Convention was adopted by Resolution A/RES/60/21 of 9 December 2005.

10 OECD Document, 4.

11 K.W. Chong, J. Chao S, "United Nations Convention on the Use of Electronic
} Communications in International Contracts: A New Global Standard" Singapore Academy of Law Journal 18/2006, 135.

12 Article 2 CISG.

13 Article 1 (1) e-CC.

14 UNCITRAL e-CC Explanatory Note,14, para 6.

15 The e-CC Preamble. Besides individual states, pursuant to Article 17 (1) e-CC regional economic integration organizations, may sign, ratify, accept, approve or accede to the Convention. However, only an organization that "has competence over certain matters governed by" the e-CC may ratify the Convention. By acceding to the e-CC, a "regional economic integration organization becomes a contracting party in its own right and has the right to submit declarations excluding or including matters in the scope of application of the Convention pursuant to articles 19 and 20." Theoretically, it is possible that both individual states and a regional economic integration organization submit declarations, which would create considerable uncertainty. However, in practice, such situations are unlikely to arise because Article 17 (2) "already imposes a high standard of coordination by requiring the 
Article 21 allows for exclusion of certain matters from the Convention's scope through declarations. For example, Singapore, among other contracts, excluded from the Convention's application contracts for the sale or other dispositions of immovable property. ${ }^{16}$ Instead of making a declaration, however, it might be wiser, to consider adjusting the domestic legal framework with the principles of the Convention, thus eliminating the duality of regimes.

\section{THE STATE OF THE LAW ON E-COMMERCE IN SERBIA}

The legal framework for e-commerce in Serbia has existed for over a decade now, yet e-commerce has yet to achieve its full potential. The National Assembly has enacted three main laws: the Law on Electronic Signature ("LES"), ${ }^{17}$ the Law on Electronic Commerce ("LEC") 18 and the Law on Electronic Document ("LED"). ${ }^{19}$ They were written with the relevant European Union directives in mind: E-signatures Directive of 1999 and E-commerce Directive of $2000 .^{20}$ The former directive, however, has since been repealed. ${ }^{21}$

The eIDAS Regulation became effective on July 1, 2016. Under eIDAS, certificates for electronic signatures are no longer issued to legal persons. ${ }^{22}$ This is different from what the previous framework, which

regional economic integration organization to declare the specific matters for which it has competence". Hence, in practice, "differing declarations from member States would be limited to matters in which no exclusive competence had been transferred" to the regional organization. See UNCITRAL e-CC Explanatory Note, 84, paras 263-265.

16 UNCITRAL, http://www.uncitral.org/uncitral/en/uncitral_texts/electronic_com merce/2005Convention_status.html, last visited 1 July 2016.

17 Law on Electronic Signature, Official Gazette of the Republic of Serbia, No. 135/2004 (“LES”).

18 Law on Electronic Commerce, Official Gazette of the Republic of Serbia, No. 41/2009 and 95/2013 ("LEC").

19 Law on Electronic Document, Official Gazette of the Republic of Serbia, No. 51/2009 (“LED").

20 Foreign Investors Council, White Book: Proposals for Improvement of the Business Environment in Serbia (eds. Prof PhD Mihailo Crnobrnja, Foreign Investors Council) 2013, 94, http://fic.rs/admin/download/files/cms/attach?id=420, last visited 15 July 2014; Directive 1999/93/EC of the European Parliament and of the Council of 13 December 1999 on a Community framework for electronic signatures ("E-signatures Directive"); Directive 2000/31/EC of the European Parliament and of the Council of 8 June 2000 on certain legal aspects of information society services, in particular electronic commerce in the Internal Market ("E-commerce Directive").

21 Regulation (EU) No 910/2014 of the European Parliament and of the Council of 23 July 2014 on electronic identification and trust services for electronic transactions in the internal market and repealing Directive 1999/93/EC ("eIDAS").

22 Article 3(9), (10) eIDAS. 
served as the basis for the Serbian LES, ${ }^{23}$ envisioned. The eIDAS further introduces electronic seals, ${ }^{24}$ a term non-existent in Serbian law. Finally, and most importantly, the trust services provided by trust service providers established in non-EU countries are considered legally equivalent to qualified trust services provided by EU qualified trust service providers only where there is an agreement between the EU and the non-EU country. ${ }^{25}$ The bottom line is that the Serbian legislation is based on an outdated EU directive and is, therefore, no longer compliant with the current state of EU Law.

The e-CC, on the other hand, is compatible with the current EU framework on e-commerce. First, it is reconcilable with the terms of eIDAS. While eIDAS focuses on public trust framework and does not encourage recognition of non-EU signatures, especially those originating from public bodies, it leaves freedom of contract for commercial operations. Second, it is compatible with the E-commerce Directive of $2000 .^{26}$ Admittedly, the focus of this Directive is the regulation of information society services, not the regulation of international contracts. However, Article 9, which deals with the formation or validity of electronic contracts, requires Member States to ensure conclusion of contracts electronically. Moreover, it requires Member States to "ensure that the legal requirements ... neither create obstacles for the use of electronic contracts nor result in such contracts being deprived of legal effectiveness or validity ..." solely because they were concluded by electronic means. ${ }^{27}$ This is the essence of the principle of non-discrimination, one of the pillars of the e-CC. Finally, "the lack of any conflict in the European Community as far as the application of the [MLEC] is concerned"28 also indicates compatibility. Among the 67 States that had adopted MLEC, three are EU Member States. ${ }^{29}$ Had the laws of these countries been non-compliant with the EU law, "the European Commission would have had the legal obligation to interfere and to enforce revisions." ${ }^{30}$ The lack of such action leads to a

23 Article 2 (13) states that certificates for electronic signatures may be issued to, inter alia, legal persons.

24 Article 3(24) eIDAS.

25 Article 14 (1) eIDAS.

26 J. B. Lambert, "The U.N. Convention on Electronic Contracting: Back from the Dead?", Michigan State University College of Law Journal of International Law, forthcoming, 6, https://papers.ssrn.com/sol3/papers.cfm?abstract_id $=2812427$.

27 Ibid.

28 W. Kilian, "The Electronic Communications Convention: A European Union Perspective", The United Nations Convention on the Use of Electronic Communications in International Contracts: An In-Depth Guide and Sourcebook (eds. A. H. Boss, W. Kilian), Kluwer Law International, The Netherlands 2008, 413.

29 Ireland, France and Slovenia. See: http://www.uncitral.org/uncitral/en/uncitral_ texts/electronic_commerce/1996Model_status.html.

30 W. Kilian, 413. 
reasonable conclusion that the e-CC, which builds on the MLEC, is compatible with the EU framework. ${ }^{31}$

If Serbia were to accede to the e-CC, a duality of regimes would be established: the Convention would apply to international transactions, while domestic transactions would be governed by national laws, inspired by outdated EU directives. The duality of regimes would impose on merchants a burden of determining the place of business of the other party, and, consequently, the nature of the contract (whether it is considered a domestic or an international transaction). ${ }^{32}$ Furthermore, even when they determine the kind of their contract, the parties may be unaware of the differences in legal treatment, which may come as an unpleasant surprise at a later stage of their relationship. ${ }^{33}$ Ultimately, the duality of regimes would entail additional business compliance costs, because merchants wishing to engage in electronic commerce would need to ensure compliance with both legal regimes. ${ }^{34}$ For these reasons, it is most efficient to adopt the Convention for cross-border transactions and amend the existing legislation accordingly, so that the Convention's principles apply to domestic contracts as well. ${ }^{35}$ For example, Australia, as one of the countries that has not yet adopted the e-CC formally, ${ }^{36}$ has in fact done so by creating or amending national laws in accordance with the Convention's provisions. $^{37}$

31 J. B. Lambert, 7. Some scholars are, nonetheless, concerned about Article 17 (4), which in their opinion opens the door to duality of regimes. Article 17 (4) states that any conflicting rules of any regional economic organization trump the provisions of the Convention. In prioritizing the former, "UNCITRAL recognized that measures to promote legal harmonization among member States of a regional organization might create a situation that was in countries where sub-sovereign jurisdictions ... had legislative authority over private law matters. It was felt that for matters subject to regional legal harmonization, the entire territory covered by a regional economic integration organization deserved to be treated in a similar way as a single domestic legal system". The exception in Article 17 (4) does not operate automatically. Rather, the priority status of regional rules needs to be set out in a declaration submitted under Article 21. See UNCTRAL e-CC Explanatory Note, 85,86, paras. 268, 270.

32 K. W. Chong, J. Chao S., 145.

33 Ibid.

34 Ibid.

35 Ibid., 134.

36 http://www.uncitral.org/uncitral/en/uncitral_texts/electronic_commerce/ 2005Convention_status.

37 L. G. Castellani, "The Contribution of a Uniform Legislative Framework for Electronic Transactions to Promoting Economic Development in the Pacific", Comparative Law Journal of the Pacific 17/2011, 24. 


\section{THE ELECTRONIC COMMUNICATIONS CONVENTION - MAIN PRINCIPLES AND THEIR INTERPLAY WITH SERBIAN LEGISLATION}

Although the e-CC builds upon the MLEC and MLES, it does not blueprint their provisions; rather it improves and updates them to take into account technological developments since $1996 .{ }^{38}$ Contrary to the two-tier approach to electronic signatures taken in MLES, the e-CC promotes the principle of technology-neutrality. Other principles on which the Convention and other UNCITRAL texts on electronic commerce are based include the principle of functional equivalence, principle of nondiscrimination and the principle of party autonomy.

\subsection{Principle of functional equivalence}

The e-CC attempts neither to replace traditional legal notions with new ones nor to define a computer-based equivalent to any particular kind of paper document. Instead, it purports "to identify the circumstances under which the same function envisaged by the law may be fulfilled by the exchange of communications in electronic form." 39 The e-CC "singles out basic functions of paper-based form requirements, with a view to providing criteria which, once they are met by electronic communications, enable such electronic communications to enjoy the same level of legal recognition as corresponding paper documents performing the same function". Consequently, the drafters of the e-CC in Article 9 (which concerns form requirements) adopted the principle of technology neutrality. ${ }^{40}$ Serbian laws, while in principle allowing technology neutrality, seem to favor public key infrastructure technology (explained in section 4 subsection 1.3.) and thus embrace the two-tiered approach. It is usually stated that legislation adopting a two-tiered system "grants electronic signatures functional equivalence with handwritten signatures, based on technologically neutral criteria". ${ }^{41}$ However, from the language of the LED it is apparent that it departs from the principle of functional

38 K. W. Chong, J. S. Chao, 119.

39 J. A. Estrella Faria, "Drafting and Negotiating History of the Electronic Communications Convention", The United Nations Convention on the Use of Electronic Communications in International Contracts: An In-Depth Guide and Sourcebook (eds. A. H. Boss, W. Kilian), Kluwer Law International, The Netherlands 2008, 22.

40 T.J. Smedinghoff, "Article 9. Form Requirements", The United Nations Convention on the Use of Electronic Communications in International Contracts: An In-Depth Guide and Sourcebook (eds. A. H. Boss, W. Kilian), Kluwer Law International, The Netherlands 2008, 139.

41 Promoting confidence in electronic commerce: legal issues on international use of electronic authentication and signature methods, United Nations, Vienna 2009, 41. 
equivalence, since, instead of focusing on the function of the form it imposes technical criteria that an electronic document must satisfy.

The provisions relevant for comparison are Article 9(2) e-CC and Article 4(2) LED. Article 9(2) e-CC requires an electronic communication to meet two conditions in order to have the same effect as a "writing" in the paper world. First, an electronic communication must be "accessible". Second, it must be "usable for subsequent reference". On the contrary, Article 4(2) LED provides that the written form is met when an electronic document is signed with a qualified electronic signature. ${ }^{42}$

Certainly, the standards envisaged in Article 9 e-CC are minimum ${ }^{43}$ and is likely that the countries would provide for additional requirements. However, requiring a qualified electronic signature as a counterpart of "writing" might be too much of an impediment for foreign parties. Moreover, "it may be more appropriate to gradually vary security requirements similarly to the way degrees of legal security are varied in the paper world" . ${ }^{44}$ Namely, qualified or digital signatures are the equivalent of notarized signatures, which are one level above plain handwritten signatures. $^{45}$

\subsection{Principle of non-discrimination}

Article 8(1) e-CC envisages that a communication or a contract shall not be denied validity or enforceability just because it is in the form of an electronic communication. The rule of non-discrimination in this article "embodies the principle of functional equivalence, and confers legal recognition to electronic functional equivalents of communication or contracts. ${ }^{46}$ Serbian legislation affirms this principle. ${ }^{47}$

\subsection{Principle of technology neutrality}

The e-CC provides for the "coverage of all factual situations where information is generated, stored or transmitted in the form of electronic communications, irrespective of the technology or the medium used". ${ }^{48}$ This principle ensures that the legislation remains capable of accommo-

42 Qualified electronic signatures in Serbian law are equated with "digital signatures" in comparative law. See: D. Prlja, M. Reljanović, Z. Ivanović, Internet i Pravo, Beograd 2012, 110.

43 UNCITRAL e-CC Explanatory Note, 16, para 14.

44 J. A. Estrella Faria (2008), 23.

45 C. M. Laborde, Electronic Signatures in International Contracts, Peter Lang, Frankfurt am Main 2010, 43.

46 K. W. Chong, J. S. Chao, 120.

47 Article 3 LES; Article 4 LED; Article 9 LEC.

48 UNCITRAL,e-CC Explanatory Note, 26, para 47. 
dating future developments and does not become outdated quickly. ${ }^{49}$ Moreover, this approach allows the parties to choose the technology that is appropriate for their needs. ${ }^{50}$

The area where the relevance of this principle is visible the most concerns electronic signatures. They are supposed to perform the same functions as handwritten signatures though adapted to the specifics of electronic transactions. ${ }^{51}$ The formats in which an electronic signature can exist vary from a name typed directly on to a document, a manuscript signature that is scanned into a document to a digital signature, created using public key cryptography. ${ }^{52}$ A click on the "I agree" button may also be considered as an electronic signature. ${ }^{53}$ According to the principle of technology neutrality, all of these types of signatures will satisfy the requirement of a signature in the paper world if a method is used to identify the signing party and that method indicates his/her intention with respect to the information contained in the electronic communication. ${ }^{54}$

Although this principle facilitates trade, numerous countries declined to follow it. Austria, Argentina, Belgium, Bermuda, Chile, China, Croatia, Czech Republic, Finland, France, Germany, Hong Kong, Hungary, India, Ireland, Mexico, Netherlands, Norway, Poland, Portugal, Romania, Republic of Korea, Russia, Singapore, South Africa, Spain, Switzerland, Taiwan, Turkey, etc. prefer the "two-tiered" or "two-prong" approach. ${ }^{55}$ Under this approach, all types of electronic signatures are allowed, however the legislation assigns greater legal effect to certain electronic authentication methods. These signatures, created using public key cryptography, are also called digital signatures. In Serbian Law they are

49 Promoting confidence in electronic commerce: legal issues on international use of electronic authentication and signature methods, United Nations, Vienna 2009, 37.

50 Ibid.

51 C. M. Laborde, 29.

52 S. Mason, Electronic Signatures in Law, Lexis Nexis, United Kingdom 2003, 78.

53 Ibid.

54 Article 9 (3) e-CC.

55 S. Mason, Electronic Signatures in Law, Lexis Nexis, United Kingdom 2012, 156, 163; "Global Guide to Electronic Signature Law: Country by Country Summaries of Law and Enforceability" https://acrobat.adobe.com/content/dam/doc-cloud/en/pdfs/adobe-global-guide-to-electronic-signature-law.pdf.

The two-tiered approach, although different from the minimalist approach, which gives a minimum legal status to all forms of electronic signature, is still regarded as technologically neutral. The two-tiered principle is the complete opposite of a technologyspecific approach. When the legislator follows a technology-specific principle, it usually demands PKI-based applications, justifying that by higher levels of security. See: Promoting confidence in electronic commerce: legal issues on international use of electronic authentication and signature methods, United Nations, Vienna 2009, 40. 
referred to as "qualified electronic signatures". ${ }^{56}$ Since the LES recognizes both qualified and unqualified electronic signatures (though more importance is attached to the latter), it may be concluded that the Serbian legislator has also opted for a two-tiered approach.

Using public key infrastructure ("PKI") means encrypting messages. Encryption, first, ensures that only people who possess the necessary "key" can access the information contained therein. Second, it prevents alterations of the message content. It is presumed that signatures based on public key cryptography are the most secure type of signature for electronic transactions. ${ }^{57}$ Indeed, Article 2 LES defines a "qualified electronic signature" as an electronic signature which guarantees with certainty the identity of the signatory, the integrity of electronic documents and prevents subsequent denial of responsibility for their content, and which fulfills the conditions stipulated in the Law. However, the "complexity of the public key infrastructure clashes with the simplicity inherent to electronic transactions." 58 In order to use a qualified electronic signature one must, first, utilize the means necessary for the formation of that signature and, second, possess a qualified electronic certificate, issued by a certification authority ${ }^{59}$ Although the LES was adopted by the Serbian Parliament in 2004, it was not until 2008 that certification authorities were created. ${ }^{60}$

Currently, there are twelve certification authorities, among which are the Chamber of Commerce of the Republic of Serbia, the Post of Serbia, the Ministry of Internal Affairs and E-Smart Systems Company. ${ }^{61}$ The validity of these certificates ranges between 1 and 5 years. ${ }^{62}$ Regarding the relationship between foreign and domestic certificates, there is an inconsistency between the legal framework and reality. While the law equates certificates issued by foreign certification authorities with domes-

56 D. Prlja, M. Reljanović, Z. Ivanović, 110.

57 C. M. Laborde, 54.

58 Ibid., 42.

59 G. Pavlović, "Implementacija elektronskog potpisa u Srbiji”, Telekomunikacije - stručno-naučni časopis Republičke agencije za elektrnske komunikacije 2016/1, http:// www.telekomunikacije.rs/archive/first_issue/g_pavlovic:_implementacija_elektronskog_ potpisa_u_srbiji.119.html, last visited 15 August 2015.

60 PKI Sistem i Sertifikaciono telo Pošte, http://www.ca.posta.rs/default.htm, last visited 15 August 2015.

61 R. Prodanović, I. Vulić, "Comparative Analysis: PKI in Serbia," http://www.infotech.org.rs/blog/wp-content/uploads/43.pdf, last visited15 August 2015.

Certificates issued by E-Smart Systems certification authority are the ones mostly used for e-commerce; certificates issued by other bodies are used for e-government, ebusiness, etc.

62 Ibid. 
tic ones under certain conditions, ${ }^{63}$ it is doubtful whether there has been any actual cooperation between domestic and foreign bodies.

One practical example where different requirements for electronic signatures raise an issue regards the form (and, consequently, the existence) of an arbitration agreement. Arbitration has, undoubtedly, become a frequently used tool in international transactions. Therefore, it is of utmost importance to determine whether arbitration agreements may be concluded electronically, and, in the affirmative, whether there are any requirements with respect to the parties' signatures. The Law on Arbitration, ${ }^{64}$ which applies to both domestic and international arbitrations, ${ }^{65}$ requires a written arbitration agreement. ${ }^{66} \mathrm{An}$ arbitration agreement is considered to be in writing if it is contained in documents that the parties have signed. ${ }^{67}$ Now, if this was the last paragraph of the provision, concluding an arbitration agreement in electronic form would be very cumbersome. This is because Article 10 LES states that only a qualified signature produces the same effect and has the same probative force as the signature in relation to data in paper form. This would then mean that the parties could not conclude an arbitration agreement in electronic form prior to obtaining electronic certificates, and that in itself would entail a whole different procedure.

Fortunately, the Serbian legislator has specifically addressed the issue of electronic arbitration agreements in Article 12(3) of the Law on Arbitration. Pursuant to this provision, an exchange of electronic messages, which provides written evidence of the parties consent, constitutes a valid arbitration agreement, even if the parties had not signed these messages. Consequently, if an arbitration agreement is concluded between a Serbian party and a business entity from a State whose legislator provides for the same rule, no problem arises. However, the problem would arise if the other State requires a signature. In that case, would the parties then have a valid arbitration agreement? Article 9(3) e-CC would spare the parties the unnecessary headache. In short, the requirement of written form would be satisfied if a reliable method, which identifies and indicates the party's intention in respect to the content of an electronic communication, was used.

63 If the certificate originates from a country with which Serbia has a bilateral agreement, or the foreign certification authority has received a decision regarding registration of the certification authority from a domestic certification authority. See Article 35 of the Law on Electronic Signature. Article 35 states that foreign and domestic certificates are equated in case of 1) a bilateral international agreement regarding recognition of qualified electronic certificates or 2) registration as a local certification authority.

64 Law on Arbitration, Official Gazette of the Republic of Serbia No. 46/2006.

65 Pursuant to Article 2 (1) the parties to an international arbitration may decide otherwise.

66 Article 12 (1).

67 Article $12(2)$ 


\section{AREAS IN WHICH THE ELECTRONIC COMMUNICATIONS CONVENTION MIGHT INSPIRE DOMESTIC LEGAL REFORM}

Firstly, the e-CC introduces one of the topics that was not addressed in the MLEC: conclusion of a contract via "automated message systems". ${ }^{6}$ An "automated message system" is "a computer program or an electronic or other automated means used to initiate an action or respond to data messages or performances in whole or in part, without review or intervention by a natural person each time an action is initiated or a response is generated by the system". ${ }^{69}$ Article $12 \mathrm{e}-\mathrm{CC}$ provides that contracts concluded without human interference, i.e. contracts concluded between an automated message system and a natural person, or between automated message systems, are equally enforceable as those concluded between natural persons. Serbian law does not specifically address that subject. A "contract in electronic form" is described as a contract concluded between natural and/or legal persons. ${ }^{70}$ This does not necessarily exclude the possibility of contracts between automated message systems, however, in the name of certainty, it might be wise to supplement domestic legislation with a similar article. ${ }^{71}$

Secondly, Article 14 e-CC provides a rule in case of error in an electronic communication exchanged with the automated message system of another party. It is the only provision "that changes substantive law rather than dealing with the effects of the medium of communication". ${ }^{72}$ Article 14 states that, if the party whose automated message system has not enabled the other party to correct an error, than the party who committed an error may "withdraw the portion of the electronic communication in which the input error was made". Serbian law imposes no such duty. It is worth stressing that the application of this article is restricted to 'input errors' made by natural persons when communicating with a machine rather than another natural person. ${ }^{73}$ Moreover, Article 14 does not affect the application of domestic rules regarding errors.

68 Article 12 e-CC.

69 Article 4 (g) e-CC.

70 Article 3 (7) LEC.

71 See A/CN.9/546, para. 124. Providing for contract conclusion via automated message systems might raise some additional issues, like the question of liability for unwanted and unintended modifications. While a legitimate concern and an interesting topic for debate and further research, it will remain outside of the scope of the present paper.

72 J. D. Gregory, J. Remsu, "Article 14. Error in Electronic Communication", The United Nations Convention on the Use of Electronic Communications in International Contracts: An In-Depth Guide and Sourcebook (eds. A. H. Boss, W. Kilian), Kluwer Law International, The Netherlands 2008, 198.

73 Ibid., 200. 
Additionally, the e-CC contains detailed rules regarding the time of dispatch and receipt of an electronic communication. ${ }^{74}$ It is assumed that an electronic communication is received when it is capable of being retrieved by the addressee. Article 15 LEC contains a similar rule, stating that electronic communications are received once they are accessible to the addressee. The e-CC, however, goes one step further and explains when it is "presumed to be capable of being retrieved". If the electronic address is designated, then the communication is received when it reaches the addressee's electronic address. ${ }^{75}$ If the address is not designated, the recipient must become aware that the message was sent. These clarifications certainly relieve the parties of the trouble of determining the time of receipt and might be a useful addition to the present LEC.

Lastly, the e-CC reaffirms the principle of technology neutrality. This principle may inspire the national legislator to modify the rules on electronic signatures. In addition to causing uncertainties in arbitral proceedings, the requirement of a qualified electronic signature poses problems to foreign parties who wish to bring their claims before national courts. For example, a foreign entrepreneur commences court proceedings against a Serbian party. All memorials, pursuant to Article 98 (1) of the Law on Civil Procedure, must be in writing. One of the necessary elements of a memorial is the signature of the submitting party. ${ }^{76}$ Now it is true that written form requirement may be fulfilled by electronic mail, ${ }^{77}$ however it is also true that pursuant to Article10 LES the signature must be qualified. A qualified signature, as it was already mentioned, means that the signor possesses a qualified electronic certificate. In order to receive this certificate one must possess a Unique Master Citizen Number ("JMBG"), ${ }^{78}$ which is inherent to Serbian citizenship. Hence, the possibility to make electronic submissions in court proceedings is not available to a foreign entrepreneur because he cannot obtain a qualified electronic certificate. Moreover, a foreigner is also precluded from giving the power of attorney electronically. Namely, the power of attorney must be in written form, ${ }^{79}$ which may be satisfied by an electronic document as well, if it

74 See: Article 10 e-CC.

75 A somewhat different approach was taken by the CISG Advisory Council. The Advisory Opinion $1 \mathrm{n}$ the comment to Article 15 states that a communication is deemed received when it reaches the addressee's server.

76 Article 98 (3) of the Law on Civil Procedure, Official Gazette of the Republic of Serbia No. 72/2011, 49/2013, 74/2013, 55/2014 (“LCP”).

77 Article 98 (2) LCP.

78 Article 11 (4), the Ordinance on the technical and technological steps for creating a qualified electronic signature and the criteria to be fulfilled by the means of creating qualified electronic signature, Official Gazette of the Republic of Serbia No. 26/2008 and $13 / 2010$.

79 Article 90 LCP. 
is signed by a qualified electronic signature ${ }^{80}$ For lack of a qualified electronic certificate, a foreign entrepreneur would be put in an uncomfortable position. The prospects of having to use regular post and thus face longer proceedings in the event of dispute, as well as the impossibility of giving the power of attorney electronically, are certainly not encouraging foreign entrepreneurs to engage in business relations with Serbian parties.

The Serbian legislator has recognized the problem which foreigners face with respect to qualified electronic signatures. In March 2015 the legislator has, by amending the Ordinance on technical and technological steps for creating a qualified electronic signature, allowed foreigners to obtain qualified electronic certificates despite the lack of a JMBG. Nevertheless, the scope of this amendment is very limited, since the JMBG is not required only for the purposes of signing financial reports. ${ }^{81}$ For other purposes, like participation in court proceedings, JMBG is still a prerequisite for the qualified electronic certificate.

While the e-CC does not purport to change national laws of procedure, the principle of technology neutrality, which underlies the Convention's provisions, coupled with practical necessity, might encourage the national legislator to extend the 'waiver' of the JMBG requirement to other situations as well, thus embracing the principle of technology neutrality.

\section{THE ELECTRONIC COMMUNICATIONS CONVENTION AND OTHER UNCITRAL TEXTS IN SERBIA}

Article 20 e-CC makes the e-CC provisions applicable to the use of electronic communications in connection with the formation or performance of a contract to which other UNCITRAL conventions apply. Serbia has adopted several UNCITRAL texts, e.g. the Convention on the Recognition and Enforcement of Foreign Arbitral Awards, 1958 (the "NY Convention"), the Convention on Contracts for the International Sale of Goods (the "CISG") and the Convention on the Limitation Period in the International Sale of Goods, 1974. All of those treaties were created in the past millennium when modern technology was either non-existent or was still making its baby steps. Some of the provisions of these treaties require adjustments in order to accommodate the needs of contemporary trade.

80 Article 4 (2) LED.

81 Article 1(2) of the Ordinance on addendums of the ordinance on the technical and technological steps for creating qualified electronic signature and the criteria to be fulfilled by the means for creating qualified electronic signature, Official Gazette of the Republic of Serbia No. 23/15. 
Two possible ways to make those treaties compatible with the use of new technologies exist. The first one requires the formal amendment of the treaty. This process, due to the conventions' wide recognition, ${ }^{82}$ would be extremely time-consuming. The second, more effective approach, requires the establishment of "general rules of functional equivalence for electronic and written requirements". ${ }^{83}$ The e-CC may be considered as a set of "general rules" and, hence, its adoption would be a logical step on the road to facilitating cross-border trade.

Parties applying the CISG would benefit from the e-CC. Although the general rule is the 'freedom of form', the parties' contract may be subject to written form either by virtue of their agreement or due to the applicability of the law of a declaring state. ${ }^{84}$ Article 12 , which allows countries to declare that the principle of informality will not apply, is the only mandatory provision of the Convention, since the parties to a contract "may not derogate from it or vary its effect". The e-CC is relevant for numerous CISG provisions, but in particular for Arts. 13 and 29 (2). The former provides a definition of "writing", which, understandably, today is considered outdated. The mention of "telegram and telex" should be understood only as exempli causa and, hence, the term writing should include electronic communications. ${ }^{85}$ Similarly, Article 29 (2), which provides that contracts in writing cannot be modified orally should also be extended to include electronic communications. However, considering that in lack of "hard law" rules it is uncertain "to what extent equivalence between electronic and written form may be achieved through the application of domestic law on electronic commerce to the contract of sale", 86 it would be desirable to enact a complete legal framework that would in a uniform way settle these issues. Such a framework is the e-CC.

Due to the misleading Serbian translation of the provision, the e-CC may also be helpful when it comes to Article 39 CISG and to the form of the notice of non-conformity. While the English version ("give notice") implies no particular form, from the reading of the Serbian version ("poslati obaveštenje" - "send notice") one may conclude that the

82 There are 156 parties to the NY Convention, while the CISG has been adopted by 85 countries.

83 L. G. Castellani (2009), 188.

84 To this date there are 8 countries that have made the Article 96 declaration: Argentina, Armenia, Belarus, Chile, Paraguay, Russian Federation, Ukraine and Viet Nam. See: http://www.uncitral.org/uncitral/en/uncitral_texts/sale_goods/1980CISG_status.html; http://www.unis.unvienna.org/unis/en/pressrels/2015/unisl219.html

85 S. Eiselen, "Electronic Commerce and the UN Convention on Contracts for the Sale of Goods (CISG)," EDI Law Review 6/1999, 35.

86 L.G. Castellani (2009), 188. 
notice must be in writing. ${ }^{87}$ Arbitral tribunals have faced this question and, based on the Serbian formulation, held that the notice of non-conformity must be in writing. ${ }^{88}$ Certainly, having in mind Arts. 7 and 101 of the CISG, as well as Article 33 of the Vienna Convention on the Law of Treaties, the English version, as one of the official versions of the CISG, should prevail. ${ }^{89}$ Nevertheless, as long as this incoherence remains, the e-CC will be of assistance.

Considering that commercial disputes are often resolved in arbitration, the parties to sales contracts would benefit from the e-CC because it would dispel any ambiguity regarding the form of an arbitration agreement. This is because the term "contract" is given a broader sense in the e-CC than in the CISG, as it encompasses arbitration agreements. ${ }^{90}$ The fact that the e-CC applies to arbitration agreements is particularly helpful, since the question of form of arbitration agreements is excluded from the scope of application of Article 11 CISG. ${ }^{91}$ Therefore, the prevailing opinion is that, even though the contract of sale may be oral, the arbitration agreement has to be put down in writing. This pre-condition stems from Article II (2) of the NY Convention, which provides that the written form requirement is satisfied by "an arbitral clause in a contract or an arbitration agreement, signed by the parties or contained in an exchange of letters or telegrams".

One might argue that the e-CC is not needed, because states parties to the NY Convention have a recommendation on how to interpret the relevant articles on form of an arbitration agreement. ${ }^{92}$ Others might say that the issue has been resolved by amending the Model Law on International Commercial Arbitration. Indeed, in 2006 the requirements as to the form of arbitration agreements set out in the Model Law were modified. The new version of the Model Law provides two variants of Article 7, which deals with the issue of form. One version mentions no form re-

87 M. Đorđević, "Konvencija UN o ugovorima o medjunarodnoj prodaji robe u srpskom pravu i praksi - Iskustva i perspective," Anali Pravnog fakulteta u Beogradu (Anali PFB) 2/2012, 271-272.

88 T-09/01 (23 February 2004); T-10/04 (6 November 2005); T-18/01 (27 November 2002).

89 V. Pavić, M. Djordjević, "Application of the CISG Before the Foreign Trade Court of Arbitration at the Serbian Chamber of Commerce - Looking Back at the Latest 100 Cases", Journal of Law and Commerce 2009, 37.

90 UNCITRAL e-CC Explanatory Note, 14, para 5.

91 Although there is an opposite view in legal doctrine. See J. Walker, "Agreeing to Disagree: Can We Just Have Words? CISG Article 11 and the Model Law Writing Requirement", Journal of Law and Commerce 25/2005-2006, 163.

92 Recommendation regarding the interpretation of article II, paragraph 2, and article VII, paragraph 1, of the Convention on the Recognition and Enforcement of Foreign Arbitral Awards, New York, 10 June 1958. 
quirements at all, while the other prescribes a writing requirement which is met by "an electronic communication if the information contained therein is accessible so as to be useable for subsequent reference." This solution is satisfactory, yet, the same problem follows this Model Law as does the MLEC and MLES: its "soft law" nature. Consequently, only a binding instrument as the e-CC is suitable to address this issue.

\section{POTENTIAL CONTRIBUTION OF THE ELECTRONIC COMMUNICATIONS CONVENTION TO SERBIA'S ECONOMY AND ICT SECTOR}

According to the Doing Business Report of the World Bank, Serbia is currently 59th out of 189 , which is a slight improvement since 2015 when it was 68th. ${ }^{93}$ One of the reasons for this ranking are the timeconsuming and costly procedures of enforcing contracts; $;{ }^{4}$ the country's ranking in this area has not changed since $2015-73 \mathrm{rd} .{ }^{95}$ According to the Networked Readiness Index of the World Economic Forum, based on the political and regulatory environment, Serbia ranks 110 out of 143 . The $\mathrm{e}-\mathrm{CC}$ is not a magic wand, however it would certainly facilitate crossborder e-commerce by providing a harmonized set of rules.

Small and medium enterprises (the "SMEs") play a crucial role in Serbian economy. SMEs form $99.8 \%$ of all business entities. ${ }^{96}$ Their share in the trade is $67.6 \%$; in gross domestic product (GDP) - 34\%, in gross social value (GSV) - 54.1\%. ${ }^{97} 4.3 \%$ of SMEs are exporters. ${ }^{98}$ Considering that the e-CC has the potential to improve their position, it may be perceived as contributing to the fulfillment of goals set in the Strategy for Support and Development of Small and Medium Enterprises and Competitiveness (2015-2020). One of the most important aims is the internalization of the business of SMEs, which the e-CC would likely be able to achieve since it applies to cross-border $\mathrm{B} 2 \mathrm{~B}$ transactions.

The e-CC also has the potential to increase e-commerce between Serbian traders and partners from particular countries, like Montenegro

93 World Bank Group, Doing Business, http://www.doingbusiness.org/data/exploreeconomies/serbia, last visited 1 July 2016.

94 According to the Doing Business Report, the approximate duration of enforcing contracts is 635 days.

95 Doing Business 2016: Serbia, 83 http://www.doingbusiness.org/ /media/GIAWB/Doing\%20Business/Documents/Profiles/Country/SRB.pdf, last visited 1 July 2016.

96 Strategy for Support and Development of Small and Medium Enterprises and Competitiveness (2015-2020), Official Gazette of the Republic of Serbia No.35/2015, 10 ("Strategy for SMEs").

97 Ibid., 9.

98 Ibid., 10. 
and the Russian Federation. According to the data of the Serbian Chamber of Commerce from 2013 Montenegro ranked as the fifth export destination ${ }^{99}$ while Russia took the fourth place. ${ }^{100}$ These countries, besides being important trade partners, are also parties to the e-CC. ${ }^{101}$ Having a set of uniform rules, which govern transactions, would certainly facilitate existing business relations and promote new ones.

Adopting the e-CC would also contribute to the growth of the information society in the country. The development of information technologies and their use in all areas has been on the country's agenda for decades. ${ }^{102}$ The Government's Strategy for the Development of an Information Society in the Republic of Serbia until $2020^{103}$ indicates e-commerce as one of the key factors that drive the development of an information society. That is why it follows on to provide that legal obstacles to e-commerce should be removed in order to achieve that purpose. ${ }^{104}$ Consequently, by directly affecting e-commerce the Convention would indirectly positively affect Serbia's information society. In a similar manner the Convention would contribute to the realization of the goals set by the Strategy of Development and Support for the Industry of Information Technologies. ${ }^{105}$

\section{CONCLUSION}

Legislators and policy-makers around the world attempt to create a legal framework for domestic and international trade, which would not hinder or diminish the gains promised by the use of new technologies. ${ }^{106}$ The e-CC is a perfect example of such attempts. Its principles of technology neutrality and functional equivalence make it the "most modern electronic commerce legislation". ${ }^{10}$

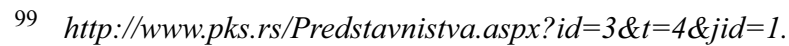

100 http://www.pks.rs/Predstavnistva.aspx? $i d=7 \& t=4 \& j i d=1$.

101 The Convention entered into force on 1 August 2014 in Russian, and on 1 April 2015 in Montenegro. See: http://www.uncitral.org/uncitral/en/uncitral_texts/electronic_ commerce/2005Convention_status.html.

102 S. Lilić, "Nauka, pravo i savremenan tehnologija", Univerzitet na pragu XXI veka, Beograd 1990, 156.

103 Official Gazette of the Republic of Serbia No. 55/05, 71/05-correction, 101/07, 65/08.

104 Official Gazette of the Republic of Serbia No. 55/05, 71/05-correction, 101/07, 65/08, 4.

105 Official Gazette of the Republic of Serbia No. 55/05, 71/05-correction, 101/07, 65/08, 16/11, 68/12, 72/12.

106 J. A. Estrella Faria (2008), 21.

107 L. G. Castellani, "Policy Considerations on the Electronic Communications Convention," Sungkyunkwan Journal of Science \& Technology Law 3/2009, 193.
} 
The e-CC was prepared as a contribution "to clarifying the legal value of electronic communications exchanged in the context of international contracts, including those falling under the regime of other trade treaties." 108 The Convention aims to, first of all, facilitate the use of electronic communications in international trade law, including in pre-existing treaties. The e-CC makes last century's treaties, such as the NY Convention and the CISG, compatible with the new millennium's technologies. Secondly, the Convention purports to increase uniformity in the enactment of the MLEC and MLES, as well as to update their provisions. Furthermore, the e-CC provides guidance on some issues that previously had either not been considered at all or had not been clearly settled (e.g., contract conclusion via automated message systems, correction of errors of automated message systems, time of dispatch and receipt of an electronic communication). Finally, the e-CC attempts to create uniform core electronic commerce legislation in countries lacking or having incomplete legislation on this issue. ${ }^{109}$

The current Serbian legislation is based on outdated EU directives. The new legal framework of the EU, in particular the eIDAS Regulation, discourages recognition of non-EU signatures. Until the day Serbia joins this community of 28 states, Article 9 (3) e-CC might serve as the bridge between EU and non-EU for cross-border recognition of e-signatures exchanged for commercial purposes. Admittedly, no simple recipe for success exists, and every solution has its advantages and disadvantages. Nonetheless, the e-CC has the potential to facilitate and bring more certainty to cross-border trade, thus giving the necessary boost to the Serbian economy and contributing to the achievement of other goals set by the Government.

\section{REFERENCES}

Castellani, L. G., "The United Nations Convention on the Use of Electronic Communications in International Contracts at Ten: Practical Relevance and Lessons Learned", Journal of Law, Society and Development $3 / 2016$.

Castellani, L. G. "The Contribution of a Uniform Legislative Framework for Electronic Transactions to Promoting Economic Development in the Pacific", Comparative Law Journal of the Pacific 17/2011.

Castellani, L. G. "Policy Considerations on the Electronic Communications Convention", Sungkyunkwan Journal of Science \& Technology Law 3/2009.

108 Ibid., 187.

109 Ibid., 188. 
Chong, K.W., Chao S J., "United Nations Convention on the Use of Electronic Communications in International Contracts: A New Global Standard", Singapore Academy of Law Journal 18/2006.

Crnobrnja M., Foreign Investors Council (eds.), White Book: Proposals for Improvement of the Business Environment in Serbia, 2013.

Đorđević, M. "Konvencija UN o ugovorima o medjunarodnoj prodaji robe u srpskom pravu i praksi - Iskustva i perspective", Anali Pravnog fakulteta u Beogradu (Anali PFB) 2/2012.

Eiselen, S. "Electronic Commerce and the UN Convention on Contracts for the Sale of Goods (CISG)", EDI Law Review 6/1999.

Estrella Faria, J. A. "Drafting and Negotiating History of the Electronic Communications Convention", The United Nations Convention on the Use of Electronic Communications in International Contracts: An In-Depth Guide and Sourcebook (eds. A. H. Boss, W. Kilian), Kluwer Law International, The Netherlands 2008.

Estrella Faria, J. A., "The United Nations Convention on the Use of Electronic Communications in International Contracts - An Introductory Note", International and Comparative Law Quarterly $55 / 2006$.

Global Guide to Electronic Signature Law: Country by Country Summaries of Law and Enforceability.

Gregory, J. D., Remsu, J. "Article 14. Error in Electronic Communication", The United Nations Convention on the Use of Electronic Communications in International Contracts: An In-Depth Guide and Sourcebook (eds. A. H. Boss, W. Kilian), Kluwer Law International, The Netherlands 2008.

Kilian, W. "The Electronic Communications Convention: A European Union Perspective," The United Nations Convention on the Use of Electronic Communications in International Contracts: An InDepth Guide and Sourcebook (eds. A. H. Boss, W. Kilian), Kluwer Law International, The Netherlands 2008.

Laborde, C. M. Electronic Signatures in International Contracts, Peter Lang, Frankfurt am Main 2010.

Lambert, J.B. "The U.N. Convention on Electronic Contracting: Back from the Dead?", Michigan State University College of Law Journal of International Law, forthcoming.

Lilić, S. "Nauka, pravo i savremenan tehnologija," Univerzitet na pragu XXI veka, Beograd 1990, 156.

Mason, S. Electronic Signatures in Law, Lexis Nexis, United Kingdom 2003.

Mason, S. Electronic Signatures in Law, Lexis Nexis, United Kingdom 2012. 
Pavić, V., Đorđević, M. "Application of the CISG Before the Foreign Trade Court of Arbitration at the Serbian Chamber of Commerce - Looking Back at the Latest 100 Cases", Journal of Law and Commerce 2009.

Pavlović, G. "Implementacija elektronskog potpisa u Srbiji”, Telekomunikacije - stručno-naučni časopis Republičke agencije za elektrnske komunikacije 1/2016.

Prlja, D., Reljanović, M., Ivanović, Z. Internet i Pravo, Beograd 2012.

Prodanović, R., Vulić, I. "Comparative Analysis: PKI in Serbia", http:// www.infotech.org.rs/blog/wp-content/uploads/43.pdf.

Smedinghoff, T. J. "Article 9. Form Requirements", The United Nations Convention on the Use of Electronic Communications in International Contracts: An In-Depth Guide and Sourcebook (eds. A. H. Boss, W. Kilian), Kluwer Law International, The Netherlands 2008.

Walker, J. "Agreeing to Disagree: Can We Just Have Words? CISG Article 11 and the Model Law Writing Requirement", Journal of Law and Commerce 25/2005-2006.

Article history:

Received: 30. 9. 2016.

Accepted: 28. 11. 2016. 